\title{
Projeto Cuidar e Ser Cuidado
}

\author{
Cavalcante, Luciana Suelly Barros; Cedotti, Walmir; Dias, Marcia Cossermeli Cana B.; \\ Saporetti, Luis Alberto; Rodriguez, Maria Del Carmen O.; Eiroz, Rosangela; Maia, \\ Fernando L. \\ Hospital das Clínicas da Faculdade de Medicina da USP — luciana.cavslcante@hc.fm.usp.br
}

Introdução: o processo de reestruturação e reforma de um hospital do município de São Paulo despertava dúvidas e angustias nos profissionais, as quais exerciam impacto no cotidiano de trabalho. Neste cenário, identificou-se uma demanda de intervenção, a qual originou a elaboração de um projeto de apoio aos profissionais e preparação dos mesmos para o momento de transição. Objetivos: o projeto caracterizou-se pela atenção aos profissionais do hospital, com objetivos de fornecer apoio psicossocial aos funcionários para o enfrentamento das mudanças previstas, promover melhorias na qualidade da assistência prestada, dissolver dúvidas referentes ao projeto para reforma e proporcionar efetiva comunicação entre as lideranças e os colaboradores. Método: o projeto foi desenvolvido baseando-se em três frentes de atuação, a saber: 1) Grupos Operativos com colaboradores, coordenados por psicanalista clínico contratado pelo hospital, compostos por 20 funcionários, sendo três encontros programados para cada grupo; 2) Grupos Operativos com as lideranças do hospital, a fim de formá-las para conduzir suas equipes durante a transição; 3) Oficinas Assistenciais específicas para profissionais de enfermagem, que consistiram em quatro workshops que abordavam a construção do cuidar a partir da interface existente entre o autocuidado, o cuidar e o ser cuidado. Buscando uma comunicação clara com os colaboradores, boletins informativos divulgavam informações sobre o andamento das negociações e processos relativos à reforma. Após os grupos e oficinas, os participantes eram convidados a preencher avaliações que mediam o impacto da intervenção através de critérios quantificáveis de satisfação e espaço para comentários livres a respeito da atividade, os quais foram elencados em categorias. Resultados: do total de 174 colaboradores, 156 (90\%) compareceram a pelo menos um encontro e 110 (63\%) participaram dos três encontros previstos. dos 156 colaboradores que participaram de um encontro, 109 (70\%) responderam à avaliação. Destes, 54,1\% considerou Muito Importante ter participado dos grupos e 63,9\% Indicaria com Certeza os grupos para os colegas. Os comentários registrados abrangiam temas relativos à "Momentos de reflexão", "Trabalhar o lado humano", "Entender melhor o colega", "Relacionamento entre chefia e funcionário", "Ética", "Comunicação", "Elogios ao conteúdo/palestrante", "Manifestação de interesse em outros encontros". do total de 63 profissionais da enfermagem, 59 participaram das oficinas assistenciais. de 57 avaliações preenchidas, 73,7\% considerou a Oficina Muito Importante e $78,9 \%$ Indicaria com Certeza a oficina para colegas de trabalho. Conclusões: Transpondo o objetivo de preparo para mudanças, o projeto Cuidar e Ser Cuidado funcionou como importante dispositivo de resgate de valores e de promoção da cultura de humanização no hospital.

Cavalcante, Luciana Suelly Barros; Cedotti, Walmir; Dias, Marcia Cossermeli Cana B.; Saporetti, Luis Alberto; Rodriguez, Maria Del Carmen O.; Eiroz, Rosangela; Maia, Fernando L.. Projeto Cuidar e Ser Cuidado. In: Anais do Congresso Internacional de Humanidades \& Humanização em Saúde [= Blucher Medical Proceedings, num.2, vol.1]. São Paulo: Editora Blucher, 2014. ISSN 2357-7282

DOI 10.5151/medpro-cihhs-10668 